\title{
PRO KONTRA KOMPARASI HUKUMAN MATI UNTUK PENGEDAR NARKOTIKA
}

\author{
Candra Tri Mardhani \\ Kantor DPRD Blitar \\ Email : candra.tri@gmail.com
}

\begin{abstract}
Abstrak
Pro kontra soal hukuman mati bagi pengedar narkotika adalah logis. elaksanaan hukuman mati terhadap pengedar narkoba atau tindak pidana pengedaran narkotika di sejumlah Negara juga mempunyai kesamaan dan perbedaan. Persamaannya, bahwa tidak setiap pengedar bisa dijatuhi hukuman mati. Hanya pengedar dengan jumlah tertentu yang bisa dijatuhi dengan sanksi hukuman mati. Mereka (masing-masing Negara) tetap dalam suatu kesepakatan untuk menjadikan pengedar narkoba sebagai ancaman serius bagi kelangsungan hidup bermasyarakat dan bernegara, khususnya dalam merusak dan menghancurkan generasi muda
\end{abstract}

Kata kunci: narkotika, hukuman mati, pengedar

\begin{abstract}
The pros and cons of the death penalty for narcotics dealers are logical. the implementation of the death penalty for drug dealers or criminal acts of drug trafficking in a number of countries also have similarities and differences. Similarly, not every dealer can be sentenced to death. Only dealers with a certain amount can be sentenced to death penalty. They (each country) remain in an agreement to make drug dealers a serious threat to the survival of society and the state, especially in destroying and destroying the younger generation
\end{abstract}

Keywords: narcotics, death penalty, dealer

\section{PENDAHULUAN}

Kasus penyalahgunaan narkotika menjadi salah satu kasus yang mengisi perkembangan kejahatan serius di dunia. Kejahatan seirius ini dikaitakn dengan dampaknya yang mengerikan terhadap generasi muda. Karena itu wajar kalau aspek hukuman yang berkaitan dengannya menjdi perbincangan, khususnya ketika diterapkan hukuman mati.

Kembali ke soal pengedaran narkoba, ibarat rayap yang menggerogoti dari celah mana pun, begitulah serbuan sindikat narkoba internasional ke Indonesia. Badan Narkotika Nasional (BNN) baru-baru ini mengungkapkan setidaknya ada tujuh negara raksasa narkoba menjadikan negara ini sebagai pasar favorit. Mereka ialah Kolombia, Peru, Bolivia, Meksiko, India, Nigeria, dan Afghanistan. Pasar narkoba di Tanah Air pun kian sesak dengan pasokan barang haram dari Malaysia, Iran, Pakistan, dan negara-negara Afrika. Padahal, beberapa tahun lalu, Indonesia cuma dijadikan negara transit oleh sindikat internasional. Namun, keuntungan besar yang didapat di Indonesia menjadi magnet bagi para gembong narkoba. 


\section{Jurnal Negara dan Keadilan \\ p-ISSN 2302-7010 e-ISSN 2721-9801}

Mereka pun lihai mencari celah untuk memasukkan barang haram itu. Para kurir narkoba akan singgah ke beberapa negara sebelum masuk ke Indonesia. ${ }^{1}$

Mereka itupun mengubah rute penerbangan dari internasional ke domestik. Pemeriksaan yang longgar di penerbangan domestik memuluskan masuknya narkoba. Sindikat narkoba juga memanfaatkan jalur laut untuk melebarkan sayap. Contohnya penemuan ratusan ribu ekstasi bernilai Rp24 miliar di Daan Mogot, Jakarta Barat, awal bulan ini. Pil setan itu dikirim dari Malaysia melalui 75 pelabuhan tikus di Kepulauan Riau. Bukan hanya lihai dalam jalur, sindikat perdagangan narkoba juga lihai dalam kamuflase. Awal Juni, BNN mengungkap penyelundupan sabu di dalam cakram mobil. Paket sabu asal India itu dimasukkan ke Indonesia melalui jasa penitipan barang. Ada pula penyelundupan sabu asal Malaysia dengan menggunakan jasa nelayan melalui perairan di Kota Tanjung Balai, Sumatra Utara. ${ }^{2}$

Kalangan bandar narkoba juga menjadikan keluarga polisi dan tentara sebagai pengguna. Ketika keluarga aparat sudah terjerat, mereka berharap para penegak hukum pun akan mau berkompromi. Bahkan jika polisi dan tentara tersebut masih terus berperang melawan narkoba, para bandar pun ikut menjadikan mereka sasaran pemasaran dengan diiming-imingi narkoba gratis. Akibatnya, jaringan narkoba bisa bertahan bahkan makin berkembang.

Dengan gempuran narkoba yang kian luas, perang pun seharusnya kian giat dilancarkan. Pemeriksaan di berbagai jalur masuk, baik udara maupun laut, internasional maupun domestik, harus sama ketatnya. Berbagai instansi terkait juga harus sama-sama mengamankan pagar depan negara ini.

Pelabuhan-pelabuhan tikus yang menjadi celah masuknya narkoba sudah saatnya diberantas. Penegakan hukum yang kuat juga tak bisa ditawar-tawar lagi. Sudah banyak kasus sangkaan terhadap bandar narkoba bisa diubah dengan uang pelicin. ${ }^{3}$

\section{METODE PENELITIAN}

Penulisan karya ilmiah ini ini, penulis menggunakan jenis penelitian bersifat deskriptif. Suatu penelitian deskriptif, sebagaimana ditulis oleh Soerjono Soekanto ${ }^{4}$ dimaksudkan untuk memberikan dan menggambarkan data yang seteliti mungkin tentang manusia, keadaan atau gejala-gejala lainya. Berdasar pengertian tersebut, penelitian ini diharapkan dapat memberikan gambaran tentang kedudukan hukuman mati bagi pengedar narkotika di Indonesia dan perbandingan hukuman mati bagi pengedar narktika di sejumlah Negara ini juga menggunakan pendekatan yang bersifat yuridis normatif. Penelitian hukum dengan pendekatan yuridis normatif ini dilakukan dengan cara meneliti bahan pustaka atau data sekunder. $^{5}$ Sumber bahan hukumnya menggunakan bahan hukum primer,

${ }^{1}$ http://metrotvnews.com/videoprogram/detail/2013/06/15/17739/121/Menghadang-GempuranNarkoba/Editorial\%20Media\%20Indonesia, akses 30 Agustus 2018.

${ }^{2}$ Ibid

${ }^{3}$ Ibid.

${ }^{4}$ Soerjono Soekanto, Metode Penelitian Hukum, (Jakarta: Sinar Grafika, 1986), hal. 9.

${ }^{5}$ Soerjono Soekanto \& Sri Mamudji, Penelitian Hukum Normatif, (Jakarta: Rajagrafindo Persada (Rajawali Grup), 2003), hal. 13-14. 


\section{Zurnal Negara dan $\mathcal{X}$ eadilan \\ p-ISSN 2302-7010 e-ISSN 2721-9801}

sekunder, dan tersiser. Teknik pengambilan bahan hukumnya menggunakan teknik dokumentasi.

\section{PEMBAHASAN}

Hukuman mati untuk pengedar narkotika Masih menimbulkan pro dan kontra. Ada kelompok yang menolak hukuman mati dikenakan pada pengedar nakotika dengan alasan hak asasi manusia atau hak keberlanjutan hidup terpidana, sedangkan ada kelompok yang menyetujui pelaksanaan hukuman mati yang juga dengan alasan demi kepentingan hak asasi manusia. ${ }^{6}$

Kelompok yang menyetujui hukuman untuk pengedar ini menilai, bahwa sanksi yang dikenakan berupa hukuman mati dapat membuat jera calon-calon pelaku yang bermaksud mengedarkan narkotika atau hak hidup banyak generasi muda ikut diselamatkan menjadi korban kecanduan narkotika akibat ketakutan di kalangan calon-calon penjahat yang bermaksud mengedarkan narkotika.

Status bandar diubah menjadi pengedar dan para pengedar disebut sebagai pemakai. Sebaliknya, pemakai kadang dianggap sebagai pelaku, bukan korban yang mesti mendapat rehabilitasi. Itulah yang membuat keluarga enggan melapor ke polisi bila ada anggota mereka kedapatan memakai narkoba karena khawatir berurusan dengan hukum.

Di sisi lain, ironisnya, ada bandar yang divonis mati dan mengendalikan bisnis narkoba dari balik jeruji justru mendapat grasi. 'Perang Bubat' melawan narkoba harus dilakukan secara komprehensif, dari hulu ke hilir, dengan melibatkan seluruh instansi terkait, juga menggalang partisipasi masyarakat. ${ }^{7}$

Dalam beberapa tahun lalu, Indonesia memang cuma menjadi negara transit atau "surga sementara" oleh sindikat internasional. Namun, label itu telah lama luntur dan mengubah wajah Indonesia menjadi destinasi penjualan (pasar transaksi dan produksi).

Indonesia semakin dipopulerkan sebagai sentra produksi narkoba, yang kondisi ini berkaitan dengan wajah hukum Indonesia yang lebih "menguntungkan" para pebisnis narkoba daripada mengubah Indonesia menjadi surga yang menyelamatkan dan mendamaikan keberlanjutan hidup generasi muda.

Selain itu, sudah demikian sering aparat kepolisian membongkar jaringan produksi narkoba. Mereka tidak jera-jeranya mendirikan pabrik barang laknat ini. Di berbagai daerah di Indonesia, kepolisian nyaris tidak mengalami atmosfir sepi dari membongkar pabrik narkoba. ${ }^{8}$

Selain jaringan produksi narkoba itu, para pebisnis global juga mendapatkan angin segar untuk mewujudkan kesempatan melakukan pembunuhan generasi muda Indonesia. Mereka semakin pemberani memasuki dan mengacak-acak keadaban dan keberlangsungan konstruksi negeri. Belum lepas dari ingatan kita, Polda Metro Jaya menyita $351 \mathrm{~kg}$ sabu asal China, Mei silam. Dua pekan

\footnotetext{
${ }^{6}$ Ahmad Supeno, Setiap Saat berjihad Menyelamatkan Generasi dari Para Bandar Narkoba, LIngkar Pengkajian dan Penelitian Bangsa (LP2B), 2016, hal. 2,,

${ }^{7}$ Ibid.

${ }^{8}$ Afrina Susiani, Narkoba: Neraka Dini, (Jakarta: Lypo-press, 2012), hal. 5.
} 


\section{$\mathcal{H}$ urnal Negara dan Keadilan \\ p-ISSN 2302-7010 e-ISSN 2721-9801}

berikutnya, aparat Badan Narkotika Nasional (BNN) mengamankan 1,5 juta pil ekstasi yang juga asal China. ${ }^{9}$

Agak tiarap beberapa saat, gembong narkoba kembali menggila belakangan ini. Pada Kamis 11 Oktober, sebanyak 2,6 kg sabu mencoba diselundupkan di Bandara Internasional Lombok, namun digagalkan aparat. Beberapa hari berselang, di tempat yang sama ini, giliran 3,7 kg hasyis atau olahan ganja dapat disita. Dari Bandara Ahmad Yani, Semarang, Jawa Tengah, $5 \mathrm{~kg}$ sabu juga hendak diselundupkan.

Memang dalam beberapa kasus, aparat berhasil membongkar jaringan produksi dan pengedaran narkoba, akan tetapi seperti teori gunung es, masih lebih banyak lagi jaringan yang tidak terbongkar akibat kelihaian para produsen dan pebisnisnya. Terbukti, data BNN menunjukkan 49,5 ton sabu, 147 juta ekstasi, 242 ton ganja, dan hampir 2 ton heroin lepas dari jerat petugas sepanjang 2011.

Berdasarkan kondisi tersebut, tidak salah jika kita menstigmatisasi Indonesia sebagai negeri darurat narkoba. Di samping jaringan produksi dan pengedaran yang kian berani, mereka sudah menghabisi 15 ribu warga setiap tahunnya, yang sebagian besar berasal dari kalangan generasi muda. Banyaknya generasi muda yang terbunuh ini logis, pasalnya mereka merupakan pasar empuk para pengedar.

Para produsen dan pebisnis narkoba yang sudah divonis dengan hukuman mati, ternyata mendapatkan grasi. Hukuman yang semula sudah memberikan vonis mati bagi perusak dan penghancur generasi muda ini, telah diubah oleh aparat penegak hukum (hakim) dengan hukuman yang bercorak memberi kesempatan hidup lebih lama, yang antara lain terhamin secara bertahap melalui upaya permintaan remisi dari momen-momen tertentu.

Kinetja aparat penegak hukum kita itu dinilai oleh banyak pihak belum beridealisme tinggi dalam membongkar atau mempengaruhi dunia produksi dan pasar distribusi narkoba, dari liberalisme (kebebasan) menuju keterbatasan, ketidaknyamanan, dan ketakutan. Mereka secara tidak langsung diberi keleluasan dan keberanian untuk terus menerus menjalankan aksinya, baik dengan jaringannya di luar penjara maupun pasar baru yang terbentuk di penjara.

Beberapa bulan lalu, hakim agung Imron Anwari menganulir vonis mati gembong narkotika Hanky Gunawan. Putusan hakim MA ini secara tidak langsung memberikan kesempatan bagi pebisnis narkoba dimanapun berada untuk menjadikan negeri ini sebagai "surga" transaksinya secara lebih leluasa.

Hakim itu barangkali berkaca pada saat Susilo Bambang Yudhoyono menjabat sebagai Presiden yang dinilai public "tidak setia" pada janjinya yang dilontarkan pada 2006, yang dalam janjinya ini tidak akan memberikan grasi kepada terpidana narkoba tanpa terkecuali, namun kenyataannya pengurangan

${ }^{9}$ Mudhofar, Pengedar Narkoba sebagai Teroris Anak Muda, makalah, FGD-LPPN, Jakarta, 2012, hal. 2. 


\section{Hurnal Negara dan $\mathcal{X}$ eadilan \\ p-ISSN 2302-7010 e-ISSN 2721-9801}

hukuman mati menjadi seumur hidup ia berikan kepada Meirika Franola pada 2011 dan Deni Satia Maharwan pada 2012. ${ }^{10}$

Terlepas apapun alasan yuridis atau politis yang dikedepankan dalam pemberian "dispensasi" hukuman pada narapidana narkoba, jelas ini berdampak besar bagi keberlanjutan hidup generasi sekarang dan mendatang. Mereka ini akan kian dijadikan lahan empuk pembantaian para produsen dan pebisnis narkoba, karena para aparat penegak hukum yang seharusnya melindungi, telah memberikan "lisensi" pembunuhan untuknya. ${ }^{11}$

Akhir-akhir ini kejahatan narkotika dan obat-obatan terlarang (narkoba) telah bersifat transnasional yang dilakukan dengan modus operandi yang tinggi dan teknologi yang canggih. Aparat penegak hukum di harapkan mampu mencegah dan menanggulangi kejahatan tersebut guna meningkatkan moralitas dan kualitas sumber daya manusia di Indonesia khususnya bagi generasi penerus bangsa. Meski demikian, kejahatan penyalahgunaan narkoba ini masih marak terjadi di masyarakat. Bahkan di beberapa kelompok masyarakat, khususnya di kalangan usia muda, ada kecenderungan terjadi peningkatan atau perkembangan modus penyalahgunaannya.

Penyalahgunaan narkoba seperti di kalangan remaja atau mahasiswa, termasuk bentuk penyalahgunaan yang memprihatinkan, karena bukan hanya dari segi kuantitas, tetapi juga dari segi kualitas penyalahgunaannya yang berdampak meluas, seperti akibatnya pada diri sendiri hingga penularannya pada anggota masyarakat lain..

Penyalahgunaan dan peredaran gelap narkotika, psikotropika, dan bahan berbahaya lainnya merupakan suatu kajian yang menjadi masalah dalam lingkup nasional maupun secara internasional. Pada kenyataanya, kejahatan narkotika memang telah menjadi sebuah kejahatan transnasional yang dilakukan oleh kelompok kejahatan terorganisir (organized crime). Masalah ini melibatkan sebuah sistem kompleks yang berpengaruh secara global dan akan berkaitan erat dengan Ketahanan Nasional sebuah bangsa. Baik secara langsung maupun tidak langsung, dalam perkembangannya hingga saat ini penyalahgunaan penggunaan narkoba tersebar secara luas pada berbagai jenjang usia dan berbagai lapisan masyarakat. Mulai dari jenjang usia muda hingga tua, kelas ekonomi bawah sampai dengan menengah ke atas. Namun yang patut mendapat perhatian lebih adalah adanya kecenderungan peningkatan angka yang signifikan pada lapis usia produktif. $^{12}$

Narkotika dan obat-obat terlarang lainnya merupakan bentuk zat yang berbeda bahan dan penggunaannya dalam ilmu kesehatan, kemudian untuk mempermudah penyebutannya, memudahkan orang berkomunikasi dan tidak menyebutkan istilah yang tergolong panjang, dengan demikian dapat disingkat dengan istilah "narkoba" yaitu narkotika dan obat-obatan adiktif yang berbahaya. Namun pada umumnya orang belum tahu tentang narkotika dan psikotropika

\footnotetext{
${ }^{10}$ Ahmad Supeno, Op.Cit, hal. 3.

${ }^{11}$ Afrina Susiani, Op.Cit, hal. 3.

${ }^{12}$ http://ferli1982.wordpress.com/2011/01/04/trend-perkembangan-narkotika-di-indonesia/, diakses 30 Agustus 2018.
} 


\section{$\mathcal{H}$ urnal Negara dan Keadilan \\ p-ISSN 2302-7010 e-ISSN 2721-9801}

karena memang dua zat tersebut dalam penyebutannya baik di media cetak maupun elektronika lebih sering diucapkan dengan istilah narkoba, meskipun mereka hanya tahu macam dan jenis dari narkoba tersebut, di antaranya ganja, kokain, heroin, pil koplo, sabu-sabu dan lain sebagainya.

Pengesahan Konvensi Wina Tahun 1971 yang mengatur kerjasama internasional dalam pengendalian, pengawasan produksi, peredaran dan penggunaan narkotika dan psikotropika serta mencegah dalam upaya pemberantasan penyalahgunaan narkotika dan psikotropika, dengan membatasi penggunaannya hanya bagi kepentingan pengobatan dan ilmu pengetahuan. Hal ini merupakan upaya pemerintah dengan penyelenggaraan kerjasama antara negara-negara lain dalam rangka suatu usaha pengawasan, peredaran dan penyalahgunaan psikotropika dan narkotika yang memberikan arahan tentang prinsip-prinsip yuridis kriminal dan aturan-aturan tentang ekstradisi.

Ditinjau dari aspek kepentingan nasional, konvensi ini dapat menjamin kepastian dan keadilan hukum dalam upaya penegakan hukum peredaran gelap narkotika dan psikotropika yang melibatkan para pelaku kejahatan lintas batas teritorial Indonesia. Di samping itu untuk kepentingan nasional, khususnya untuk kepentingan didalam negeri, akan diperoleh suatu kepastian dan kemanfaatan dalam rangka pengaturan peredaran narkotika dan psikotropika untuk kepentingan pengobatan dan ilmu pengetahuan. ${ }^{13}$

Pada dasarnya peredaran narkotika dan obat-obat terlarang lainnya di Indonesia apabila ditinjau dari aspek yuridis adalah sah keberadaannya, UndangUndang Narkotika dan Undang-Undang Psikotropika hanya melarang terhadap penggunaan psikotropika dan narkotika tanpa izin oleh undang-undang yang dimaksud. Keadaan yang demikian ini dalam tataran empirisnya, penggunaan narkotika dan psikotropika sering disalahgunakan bukan untuk kepentingan pengobatan dan ilmu pengetahuan. Akan tetapi jauh dari pada itu, dijadikan ajang bisnis yang menjanjikan dan berkembang pesat, yang mana kegiatan ini berimbas pada rusaknya mental baik fisik maupun psikis pemakai narkoba khususnya generasi muda.

Penegakan hukum terhadap tindak pidana narkotika, telah banyak dilakukan oleh aparat penegak hukum dan telah banyak mendapat putusan hakim. Dengan demikian, penegakan hukum ini diharapkan mampu menjadi faktor penangkal terhadap merebaknya perdagangan gelap serta peredaran narkotika dan psikotropika, tapi dalam kenyataannya justru semakin intensif dilakukan penegakan hukum, semakin meningkat pula peredaran serta perdagangan gelap narkotika dan psikotropika tersebut.

Ketentuan perundang-undangan yang mengatur masalah narkotika dan psikotropika telah disusun dan diberlakukan, namun demikian kejahatan yang menyangkut narkotika dan psikotropika ini belum dapat diredakan. Dalam kasuskasus terakhir telah banyak bandar-bandar dan pengedar narkoba tertangkap dan

${ }^{13}$ Siswantoro Sunarso. Penegakan Hukum Dalam Kajian sosiologis. (Jakarta: Raja Grafindo Persada, 2004.). Hhal. 1. 


\section{Hurnal Negara dan Xeadilan \\ p-ISSN 2302-7010 e-ISSN 2721-9801}

mendapat sanksi berat, namun pelaku yang lain seperti tidak mengacuhkan bahkan lebih cenderung untuk memperluas daerah operasinya. ${ }^{14}$

Penegakan hukum terhadap kejahatan di Indonesia, khususnya dalam hal pemidanaan, seharusnya merujuk pada pendekatan norma hukum yang bersifat membina penjahat dengan cara melakukan pembinaan di lembaga pemasyarakatan, dengan demikian dapat memperbaiki terpidana di lembaga pemasyarakatan tersebut. Seharusnya hal ini mampu memberikan wacana kepada para hakim dalam merumuskan vonis penjatuhan pidana kepada para pelaku kejahatan agar mampu menangkap aspirasi keadilan masyarakat, khususnya dalam soal vonis hukuman mati. Sementara itu, dalam kenyataan empiris di bidang pemidanaan secara umum masih menganut konsep hanya menghukum terpidana di lembaga pemasyarakatan, dengan demikian dapat memberikan gambaran bahwa kejahatan tersebut hanya terhenti sesaat dan akan muncul kembali dalam lingkungan kehidupan sosial masyarakat. Hukuman mati dapat menjadi alternative untuk pengedar.

\section{PENUTUP}

Kedududkan hukuman mati terhadap pengedar narkotika secara yuridis sudah jelas, meskipun kalau dikaitkan dengan aspek hak asasi manusia masihlah menimbulkan pro dan kontra. Dalam kajian hukum positip Indonesia sudah diatur dalam Undang-Undang Nomor. 35 tahun 2009 tentang Narkotika. Dalam Undang-Undang Nomor. 35 tahun 2009 terdapat sanksi pidana mati sebagaimana terurmus dalam pasal 113, 114, 118, 119, 121, 144. Pasal-pasal ini sudah jelasjelas mengatur tentang kedudukan pengedar narkotika yang bisa dijerat atau dikenai sanksi dengan hukuman mati. Sanksi hukuman mati ini selain menjadi tugas dan kewenangan hakim untuk memutuskan saat terdakwanya diperiksa dan terbukti melakukan tindak pidana pengedaran narkoba, juga ditentukan oleh peran jaksa penuntut umum yang mengajukan tuntutan hukuman mati terhadap pengedar. Selain vonis ini ditentukan oleh aparat penegak hukum ini, presiden yang mempunyai hak prerogatif berupa grasi dapat menentukan atau mempengaruhi vonis pengadilan yang sudah mempunyai kekuatan hukum tetap.

\section{DAFTAR PUSTAKA}

\section{Buku dan Makalah}

Afrina Susiani, 2012, Narkoba: Neraka Dini, Jakarta: Lypo-press. Ahmad Supeno, 2016, Setiap Saat berjihad Menyelamatkan Generasi dari Para Bandar Narkoba, LIngkar Pengkajian dan Penelitian Bangsa (LP2B), Malang.

${ }^{14}$ O.C. Kaligis \& Associates. Narkoba dan Peradilannya di Indonesia, Reformasi Hukum Pidana Melalui Perundangan dan Peradilan. (Bandung: Alumni. 2002), hal. 260. 


\section{Jurnal Negara dan Keadilan \\ p-ISSN 2302-7010 e-ISSN 2721-9801}

Mudhofar, 2012, Pengedar Narkoba sebagai Teroris Anak Muda, makalah, FGDLPPN, Jakarta.

Soerjono Soekanto, 1986, Metode Penelitian Hukum, Jakarta: Sinar Grafika.

Soerjono Soekanto \& Sri Mamudji, 2003, Penelitian Hukum Normatif, Jakarta: Rajagrafindo Persada (Rajawali Grup).

Siswantoro Sunarso. 2004, Penegakan Hukum Dalam Kajian sosiologis. Jakarta: Raja Grafindo Persada.

O.C. Kaligis \& Associates. 2002, Narkoba dan Peradilannya di Indonesia, Reformasi Hukum Pidana Melalui Perundangan dan Peradilan. Bandung: Alumni.

\section{Internet}

http://metrotvnews.com/videoprogram/detail/2013/06/15/17739/121/Menghadang -Gempuran-Narkoba/Editorial\%20Media\%20Indonesia, akses 30 Agustus 2018.

http://ferli1982.wordpress.com/2011/01/04/trend-perkembangan-narkotika-diindonesia/, diakses 30 Agustus 2018. 